
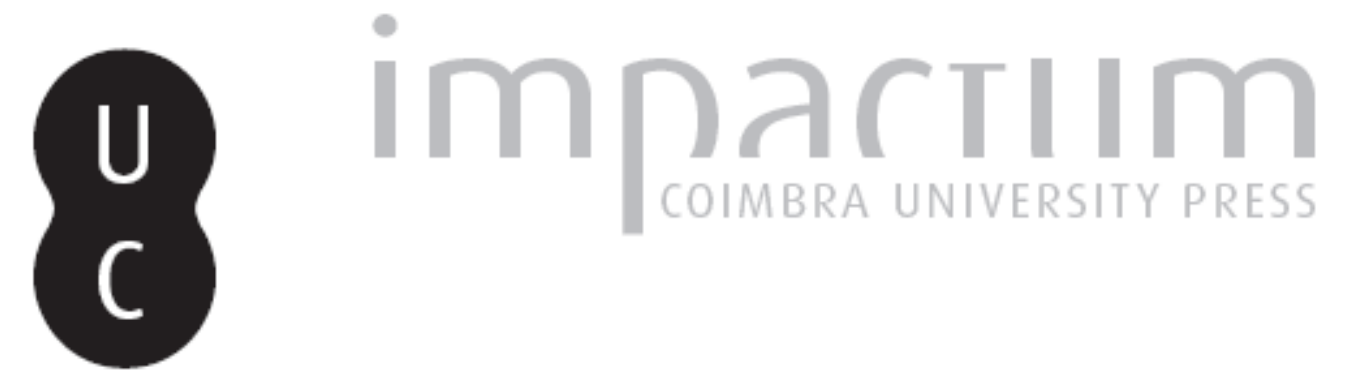

\title{
Socratic Silence in the Cleitophon
}

\section{Autor(es): $\quad$ Pichanick, Alan}

Publicado por: Imprensa da Universidade de Coimbra

URL persistente:

URI:http://hdl.handle.net/10316.2/43596

DOI:

DOI:https://doi.org/10.14195/2183-4105_17_4

Accessed : $\quad$ 26-Apr-2023 12:20:17

A navegação consulta e descarregamento dos títulos inseridos nas Bibliotecas Digitais UC Digitalis, UC Pombalina e UC Impactum, pressupõem a aceitação plena e sem reservas dos Termos e Condições de Uso destas Bibliotecas Digitais, disponíveis em https://digitalis.uc.pt/pt-pt/termos.

Conforme exposto nos referidos Termos e Condições de Uso, o descarregamento de títulos de acesso restrito requer uma licença válida de autorização devendo o utilizador aceder ao(s) documento(s) a partir de um endereço de IP da instituição detentora da supramencionada licença.

Ao utilizador é apenas permitido o descarregamento para uso pessoal, pelo que o emprego do(s) título(s) descarregado(s) para outro fim, designadamente comercial, carece de autorização do respetivo autor ou editor da obra.

Na medida em que todas as obras da UC Digitalis se encontram protegidas pelo Código do Direito de Autor e Direitos Conexos e demais legislação aplicável, toda a cópia, parcial ou total, deste documento, nos casos em que é legalmente admitida, deverá conter ou fazer-se acompanhar por este aviso. 
ISSN 2079-7567 eISSN 2183-4105

0

\section{Established 1989}

http://platosociety.org/

\section{Papers}

Cristina lonescu Elenchus, Recollection, and the Method of Hypothesis in the Meno

Lucas Soares

La relectura positiva de la tradición poética griega en el Banquete de Platón

Etienne Helmer Le commerce de la vérité: économie et commerce dans les Lois de Platon

Alan Pichanick

Socratic Silence in the Cleitophon

Thanassis Gkatzaras The Form of the Good in Plato's Timaeus

James M. Ambury Dialectical Epimeleia:

Platonic Care of the Soul and Philosophical Cognition
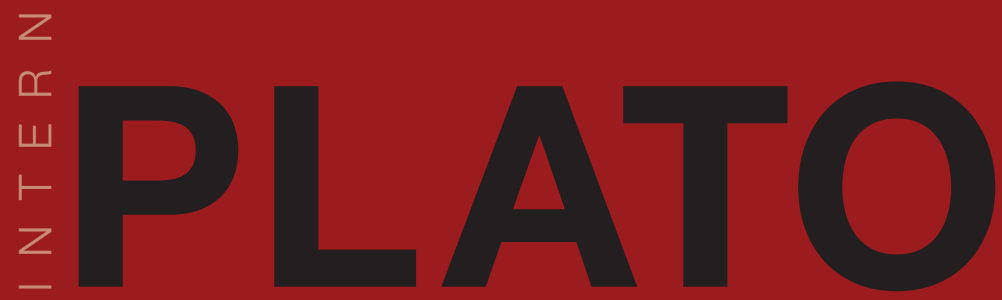

Book Reviews

Nicholas Zucchetti

Essays on Plato's Epistemology by Franco Trabattoni

Alan Pichanick

Socrates and Self-Knowledge by Christopher Moore
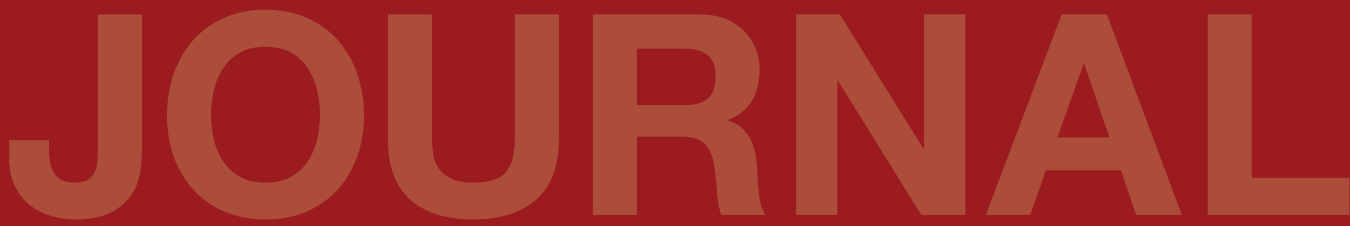

Société Platonicienne Internationale

Associazione Internazionale dei Platonisti

Sociedad Internacional de Platonistas

Internationale

Platon-Gesellschaft

Imprensa da

Universidade

de Coimbra

Coimbra

Universiy

Press 


\section{Socratic Silence in the Cleitophon}

\author{
Alan Pichanick \\ Villanova University \\ alan.pichanick@villanova.edu
}

\section{ABSTRACT}

Plato's Cleitophon is the only dialogue in which Plato presents an unanswered rebuke of Socratic philosophy by an interlocutor. Consequently, most commentators have thus rejected the dialogue as inauthentic, or have otherwise explained away the bewildering Socratic silence at the dialogue's conclusion. In this paper I explore why Socrates chooses silence as the response to Cleitophon's rebuke of Socrates. I argue that (and why) Socratic silence is the only way of "talking" with Cleitophon: Cleitophon's "Socratic speech" implies notions about nomos, the soul, and philosophy that turn out to be uniquely anti-Socratic. The dramatic disjunctions between Cleitophon's distorted image of Socrates and the real Socrates, and between Cleitophon himself and Socrates, not only make most poignant the tension between the philosopher and the city but also point to the very conditions of philosophical dialogue.

Keywords: Cleitophon, Eros, Self-knowledge, Socratic Circle, Protreptic, Apology
Plato's Cleitophon, and our relationship to it, is strange. The dialogue is woefully short, and isn't really a dialogue at all. Cleitophon levels charges against Socrates that are never taken up and answered. Socrates, much to our irritation, does not respond to Cleitophon as we expect. In fact, after what is really Cleitophon's monologue, Socrates does not speak at all. He is silent. Many scholars have therefore wondered whether the dialogue is incomplete, or perhaps even spurious or inauthentic. Few scholars have thus taken seriously the charges brought forth by Cleitophon in the dialogue.

In this paper, I take seriously the idea that this dialogue, which isn't really a dialogue, is nonetheless a completed whole, written by Plato. The subject of my paper is thus the very problematic Socratic silence at the end of the dialogue. I would like to discuss the possibility that Plato concludes this dialogue with Socrates' silence in order to show the nature, possibilities, and limitations of Socratic philosophical dialogue itself as it is manifest in the polis, and how this is revealed through his interaction (and lack thereof) with Cleitophon.

Let me begin by asking: Who is Cleitophon? Apart from his appearance in the dialogue that bears his name, Cleitophon is present in Plato's far better known dialogue, the Republic. Cleitophon makes a brief assertion in Book 1, in an attempt to defend a position of Thrasymachus. (Socrates says that Cleitophon has "praised the company of Thrasymachus" at the beginning of the Cleitophon. $)^{1}$ This assertion turns out to shed a good deal of light on the exchange in the Cleitophon itself.

Consider what Cleitophon actually says in the Republic. Socrates has just shown Thrasymachus a difficulty lurking in his claim that justice is the advantage of the stronger. The difficulty lies in the possibility for rulers to make errors and thus unintentionally make laws that 
are not to their advantage. The people subject to these laws will follow them and thereby end up doing what is not actually to the advantage of the rulers. Thus the people will, in fact, end up doing what is unjust. So if Thrasymachus is saying that justice is what the people must do and what is advantageous to the stronger, it looks that he is facing a contradiction. When the ruler is in error, either they must not do what the ruler says or they must do what is not to his advantage.

It is at this point that Cleitophon interrupts to assert that "the advantage of the stronger is what the stronger believes to be his advantage. This is what must be done by the weaker, and this is what [Thrasymachus] set down as the just." ${ }^{2}$ The silence after Cleitophon's assertion is striking. Thrasymachus does not accept this assertion as his own definition but proceeds down a different avenue. Nor does Socrates take up Cleitophon's definition of justice at that point. Nor (in parallel to the Socratic silence at the end of the dialogue that bears his name) does Cleitophon speak after this moment. This is further confirmation that these two dialogues form some kind of pair. For a similar question must emerge in the Republic, as it does in the Cleitophon. Why is silence the after-effect to Cleitophon's assertions in both places? ${ }^{3}$

Let us therefore consider what Cleitophon's statement in the Republic suggests about him about his understanding of justice, in particular. Cleitophon's position is the embodiment and spokesman for the un-questionability of the ruler's belief. ${ }^{4}$ Cleitophon regards it as a perfectly cogent position that justice could be what he believes is to his advantage, whether it is or it is not. Justice would thus require that people obey the rulers even if the rulers mistake what is to their advantage. Justice is obedience to the law, period, which in this case, means obedience to the beliefs of the ruler. ${ }^{5}$ With that in mind, we are ready to turn to Cleitophon's remarks in the dialogue that bears his name.

The Cleitophon itself begins in a strange way. Socrates reports to an unspecified "us" what he heard from an unspecified "someone": that Cleitophon has "criticized spending time with Socrates, while he could not praise too highly the company of Tharasymachus". All of this is cold, impersonal. Socrates talks about himself in the third person, and talks about Cleitophon as if he is not present. This odd beginning makes us think that Socrates is talking to at least one person other than Cleitophon and giving Cleitophon the cold shoulder, but Cleitophon soon claims that he and Socrates are alone. ${ }^{6}$

The isolated conversation between Socrates and Cleitophon presents us with a kind of image of Plato's Apology. ${ }^{7}$ In the Apology, the philosopher is compelled to come before the crowd to answer the city's charges against him. He must, if he is to survive, essentially give a non-philosophical defense of philosophy for the polis. ${ }^{8}$ Here, however, there is no crowd and the opening of this dialogue is in fact a charge, but aimed against Cleitophon, not Socrates. So at first glance it may appear that the question of Cleitophon's diatribe against Socrates seems to be: is philosophy after all useless (or dangerous) to the city? But in fact, we should be wondering whether the city has any grounds to defend itself against the philosopher. Can the polis, if it is to survive, defend itself on grounds that are acceptable to the philosopher? That is, Does Cleitophon - as representative of spokesman for the city as it is - successfully defend himself? If so, what would it mean that silence from Socrates is the judgment or verdict?

My own view is that it is under Cleitophon's understanding of law - in which the ruler's beliefs circumscribes the whole so that there 
is no good determined beyond what the ruler's will has determined - that we human beings are, in Michael Davis' terms, "fundamentally alone”. Because in Cleitophon's whole, both philosophy and soul evaporate. Those who do not live philosophically are truly alone, trapped in the web of their own unquestioned beliefs, so well described by Cleitophon in Republic I. Such anti-philosophical souls live analogously to the tyrant described in Republic IX:

So then, isn't this the kind of prison in which the tyrant is chained? He has the nature we have described, full of many and varied fears and lusts. And greedy though his soul is, he is the only one living in the city who cannot go abroad anywhere, or go and see any of the places other free men are keen to see. He spends most of his life buried in his house... (579b-c)

Cleitophon appears not to be driven by lusts. But there may be a real fear that plagues him, that prevents him from ever really "going anywhere", to speak loosely. Cleitophon is a self-appointed disciple who seeks to be a member of what he sees as a Socratic inner circle. The opening charge against him, that he has been critical of Socrates while praising Thrasymachus, should make us wonder what he wants from Socrates that he thinks he can gain from Thrasymachus. It is important to note that Socrates claims never to teach anybody, period. Socrates is not looking for disciples: the words, "Come. Follow Me," are not words that Plato's Socrates would utter."

So what then is Cleitophon's praise and censure of Socrates? Cleitophon begins his description, "When I was together with you I was amazed at what I heard. You seemed to surpass all other human beings...taking human beings to task like a god on the tragic stage..." (407a) Cleitophon's description of being with Socrates is not dialogic. His praise of Socrates is the praise of authority - godlike, lawgiving, exhortative, ruling authority. It is the power of a preacher or prophet that amazes Cleitophon and causes wonder in him. (408e.)

There are two moments in Socrates' stirring speeches that Cleitophon in his selfappointed role as disciple finds especially wondrous. First, Cleitophon reports that he has learned that cities need friendship (407cd; 409d) and secondly, Cleitophon says that he has understood that one who does not know how to use one's own soul must "hand over the rudder of his own thought to the statesman", who possesses the art of piloting human beings, which very art is justice itself (408b).

These two themes taken together, I claim, give us the view of the Cleitophontic whole, which is through and through anti-Socratic. For although we see Socrates utter sentences with these very same words in other dialogues, we must ask: what do the words mean to Cleitophon? For Socrates, if friendship is finally possible, it must be philosophically rooted, and such philosophical pursuits ultimately cause division rather than unity within the polis. For Socrates, the only reason one would ever hand over the rudder of his thought to another is when one comes to the realization that one does not know the issue at hand.

Cleitophon does not speak as one who recognizes his own aporia. His apparent "learning from Socrates" belies a complete lack of movement in his soul. What he has "learned" from Socrates has been incorporated into the way he sees things, and this has distorted Socrates' teaching. As a disciple, he has imbibed - if only wisdom were like water ${ }^{10}$ - what Socrates has poured in, and now he waits for the next offering. 
So for Cleitophon, the aim of the ruler is to create harmony in the city between apparently discordant elements and the aim of the ruled, if their souls are not already in line, is to subject themselves willingly to the ruler. Any apparent discord must vanish because there is no good determined beyond the will of the ruler; what appears good from the standpoint of the lawgiver is the good. Pushed to its conclusion, Cleitophon's view implies that there are in fact no real individual subjects in a happy city. There emerges empty abstractions: people are de-particularized members of classes, homogenized so that they may be unified, not souls at all but legal subjects.

What is completely missing from Cleitophon's description of Socrates' godlike exhortations is any notion (indeed, any mention) of philosophy, or any erotic activity at all. Cleitophon himself appears to be all thumos, no eros. Cleitophon's move from praise to censure of Socrates concerns the question: "what next?". I would like to suggest that this question - Cleitophon's question - is not asked in a philosophical spirit. It is not motivated by wonder. It shows, once and for all, that he has not really awoken from the dogmatic slumber he describes. ${ }^{11}$ What then moves Cleitophon? It is not a desire for wisdom, as may appear to be the case by his seemingly Socratic examination of others. ${ }^{12}$ It is not even a fear of his own ignorance of what is best for him. It is a fear of surrendering power in the face of what one does not know, a fear that prevents inquiry into the fundamental questions Socrates asks. Such a fear is not uncommon and may even be natural, but if it is not exposed and recognized for what it is, then it threatens philosophical discourse itself.

Cleitophon's question as formulated assumes that philosophy is a techne, like others, with a product or object distinct from its activity. One tells a better technician or craftsman, in great part, by judging these objects or products. Consider the doctor in relation to her patients, the cook in relation to her meals, the carpenter in relation to her houses. Cleitophon is taken with the idea that the object of justice is friendship in cities ${ }^{13}$ but does not sufficiently raise the question how this relates to virtue of the soul, and he does not consider at all that philosophy (or better: education that aims at the good human being), can't be modeled on a techne, whose product is clearly distinct from its process. The goal of a good human being, finally, may not involve "finding the right kind of object...but becoming the right kind of subject." 14

It is here that philosophy - the erotic pursuit of wisdom, which is always both pointing beyond itself and re-evaluating and re-describing itself, is utterly in tension with the whole circumscribed by Cleitophon's rulers. In its obliteration of the distinction between apparent and real, Cleitophon's view denies anything outside itself and can neither take up a standpoint from which to examine itself. But the city as it is, ruled by the ruler's beliefs and nothing else, is blind to such a possibility. To attempt to describe such a goal in terms the city can understand is only to utter nonsense. There is no content for the "exhortation of what comes next" to Cleitophon, if one is Socrates. To sum up: It is the one who praises the self-ignorant ruler who sees no good beyond the realm of his beliefs that demands that philosophy be exhortative and describe what goal we should be moving towards on the model of a techne.

So these two visions of the whole - Socratic, philosophical eros and Cleitophon's tyrannical nomos - cannot be reconciled to one another at all. Nor can they even talk to one another. The silence in response to Cleitophon is a response that Cleitophon's claims about justice in the polis are so deeply antithetical to Socratic 
philosophy that dialogue between them is impossible. Does this then mean that philosophy is finally useless to the city, according to Plato? If I am right, then this - in a way - is also the wrong question. Cleitophon has failed to explain and defend himself on grounds that the philosopher will accept. Socrates' silence at the end of the dialogue is thus not a condemnation of philosophy, but of Cleitophon's inevitable failure to understand the nature of philosophy, thereby remaining perpetually self-ignorant (on philosophical grounds).

But what we should note in conclusion is that Plato does not therefore silence Cleitophon. Plato is not afraid to let Socrates be accused and thus shows that the philosophical life may be one that incorporated opposing views into the same whole. For Plato dramatically incorporates both Cleitophon and Socrates and thereby implies that the proper standpoint is not to reject the anti-logos that Cleitophon puts forward. The Platonic dialogue holds together both Socratic philosophical discourse and its Cleitophontic counterpart, even if perhaps tragically the polis cannot.

\section{BIBLIOGRAPHY}

Blits, Jan. “Socratic Teaching and Justice: Plato's Cleitophon" Interpretation 13:3 (1985)

Bowe, G.S. "In Defense of Clitophon" Classical Philology, 102:3 (2007)

Davis, M. The Soul of the Greeks (Chicago, 2011)

Kremer, M. Plato's Cleitophon: On Socrates and the Modern Mind (Lexington, 2004).

Lear, J. Thereapeutic Action. (Karnac, 2003)

Orwin, C. "On the Cleitophon" in The Roots of Political Philosophy edited by T. Pangle (Cornell, 1987)

Plato, Cleitophon. Translated by C. Orwin In The Roots of Political Philosophy edited by T. Pangle (Cornell, 1987)

Roochnik, D. The Tragedy of Reason (Routledge, 1990)

C. J. Rowe, "Cleitophon and Minos," in The Cambridge History of Greek and Roman Political Thought, ed. by C. J. Rowe, M. Schofield, 303-309. Cambridge: CUP, 2000

S. R. Slings, Plato: Clitophon (Cambridge Classical Texts and Commentaries 37), Cambridge: CUP, 1999

\section{NOTES}

1406a. It is for reasons like this that the Cleitophon and the Republic are seen as some kind of pair. Most commentators would suggest that the Republic follows the Cleitophon dramatically. For an argument that there is no definitive answer to this question, see Davis Soul of the Greeks, 161.

$2340 \mathrm{~b}$. A similar argument is used by Socrates against Polemarchus: mistaking who your friends and enemies are is very similar to mistaking what is to your advantage. See 334c.333 See 334c-d.

3 One might object that it is not entirely true that Cleitophon's assertions in the Republic are followed by silence, for the simple reason that we get the following short exchange: "Well, that wasn't what was said," replied Polemarchus.

"It doesn't matter, Polemarchus," I said, "but if that is now what Thrasymachus maintains, let us accept it as it is. So tell me, Thrasymachus, was this how you wanted to define justice: that it is the advantage of the stronger as it appears to the stronger, whether it really is to their advantage or not? Is that how we are to take what you said?" To this Thrasymachus replies:

"Not in the least," he replied; "do you really imagine I call someone who makes a mistake stronger at the moment when he makes his mistake?" (340c)

But it is important to note that neither Polemarchus nor Thrasymachus are willing to pick up Cleitophon's suggestion. Socrates does ask Thrasymachus if he wishes to adopt it, but never explicitly says that he will discuss this alternative once Thrasymachus disavows it.

4 In Orwin's words, Cleitophon "asserts what Socrates gets Thrasymachus to deny, that the will of the rulers is beyond appeal... In never wavering from his interested attachment to legeal justice, he is the sole character in the Republic who stands first and last for the city as it is..." See Orwin, 130-1131. Cf. Davis, 164-165; Roochnik, 105; Kremer 26; Blits, 82-83. Slings counters that such an approach may be relevant to the passage in the Republic, but not to the Cleitophon in which there is no enmity shown towards Socrates. See Slings, 57. I think that Slings' rejection of Orwin's view is too hasty and will present reasons for why the Cleitophon in the Cleitophon matches the one Orwin describes in the Republic.

5 This position may reflect the stance Socrates takes towards his own death sentence in the Crito when he himself speaks to Crito as an embodiment of the laws of the city. If so, the argument I will be presenting here should 
raise two questions: whether the philosopher can make an adequate response to the laws presented as such, and whether this impugns the presentation of the laws of the city presented in the Crito. For if, as I will argue, Socrates' silence in the Cleitophon is the only possible response, it is still a response that calls into question the legitimacy of Cleitophon's charges. It is in this light that Socrates' presentation of the laws in the Crito could be seen. 6 See 406a. Davis discusses how this line is a way into the heart of the Cleitophon. He claims that the line provokes wonder about the possibility that human beings are all fundamentally alone, and that therefore we must doubt the very possibility of a common good or justice itself. The dialogue opens the door to tragedy. I think Davis is right to highlight the significance of this feature of the dialogue, but my own response to it moves in a somewhat different direction.

7 See Orwin, 120. What Orwin calls a "counter-Apology" is on the right track. But I do not think that Socrates remains on trial here. Rather, it is Cleitophon who must defend himself. If this is the case, however, Socrates' silence could also be a literary convention since Athenian judicial praxis usually did not allow a further response by the accuser (in this case, Socrates). This would also fit with Socrates claim at the beginning of the dialogue that he will be Cleitophon's student and is not going to say anything. Cf. Slings 13-18, 43-46. But this leaves unexplained the deeper puzzle: why would Plato present and leave unanswered these charges against Socrates? A response to this question requires a more substantive claim about the purpose of the dialogue as a whole. 8 I would suggest that Socrates' own defense speech in the Apology does not succeed in providing a non-philosophical defense of philosophy and the Cleitophon may give some reasons why. However, my account here does not rely on this claim.

9 At Republic 432c, for example, he suggests that Glaucon should follow him. The context makes clear that he is not requesting that Glaucon should be his disciple, but that he should be his partner in inquiry. Cf. $474 \mathrm{c}$

10 Cf. Symposium 176d.

$11407 c$.

12 I agree with Slings that this episode in the dialogue is constructed to resemble a parody. Slings, 3, 93, 102. Cf. Rowe, 305-306.

13 409d.

14 Lear, 86. It is noteworthy that it is not only students of Strauss who use this language in speaking about the Cleitophon. Cf. Slings 170, 175-176. Orwin is right to highlight the disappearance of music and gymnastic from Cleitophon's examples. Such "arts" are hard to describe on Cleitophon's model. See Orwin 1987, 126-127. 